\title{
DISTRIBUSI RADIONUKLIDA ALAM PADA SAMPEL TANAH, AIR DAN TANAMAN DI SEKITAR PLTU REMBANG
}

\section{DISTRIBUTION OF NATURAL RADIONUCLIDE IN SOIL, WATER AND PLANT SAMPLES AROUND THE REMBANG COAL POWER PLANT}

\author{
Sri Murniasih, Sukirno \\ PSTA - BATAN, Jl. Babarsari Kotak Pos 6101 ykbb Yogyakarta 55281 \\ E-mail: smurni83@gmail.com
}

Diterima 12 Januari 2018, diterima dalam bentuk perbaikan 25 Oktober 2018, disetujui 13 Pebruari 2019

\begin{abstract}
ABSTRAK
DISTRIBUSI RADIONUKLIDA ALAM PADA SAMPEL TANAH, AIR DAN TANAMAN DI SEKITAR PLTU REMBANG.Telah dilakukan penelitian radioaktivitas pada sampel air, sedimen dan tanaman (daun singkong) di sekitar Pusat Listrik Tenaga Uap (PLTU) Rembang.Tujuan penelitian ini adalah mengetahui kandungan radionuklida ${ }^{226} \mathrm{Ra},{ }^{228} \mathrm{Ra}$, ${ }^{232} \mathrm{Th}$ dan ${ }^{40 \mathrm{~K}}$ dalam air, tanah dan tanaman yang mencerminkan data lingkungan terkini dalam rangka mendukung program monitoring lingkungan dari pencemaran radioaktivitas di sekitar PLTU Rembang. Pengambilan sampel, preparasi maupun analisis mengacu pada prosedur analisis sampel radioaktivitas lingkungan.Radionuklida alam diukur dengan spektrometri gamma yang dilengkapi detektor HPGe terakreditasi oleh ISO 17025 tahun 2008. Hasil yang diperoleh menunjukkan radioktivitas dalam air berkisar (0,90-52,0) mBq/L,dalam tanah berkisar (100,06-760,30) Bq/kg sedangkan dalam daun singkong berkisar $(24,59$ - 60,96) Bq/Kg. Berdasarkan PERKA BAPETEN. No 7 Tahun 2017, nilai batas radioaktivitas di air yang diijinkan berkisar (730 - 1000) mBq/L, sedangkan hasil analisis air yang terdapat disekitar PLTU Rembang masih di bawah nilai batas yang dijijnkan oleh BAPETEN.
\end{abstract}

Kata kunci : radioaktivitas alam, spektrometri gamma,air, tanah dan singkong

\section{ABSTRACT}

DISTRIBUTION OF NATURAL RADIONUCLIDE IN SOIL, WATER AND PLANT SAMPLES AROUND THE REMBANG COAL POWER PLANT.Research on a sample of environmental radioactivity in the form of water, soil and plant (cassava leaves) around in the Rembang Coal Power Plant (CPP) has been conducted. The purpose of this study was to determine the contents of ${ }^{226} \mathrm{Ra}$, ${ }^{228} \mathrm{Ra}$, ${ }^{232} \mathrm{Th}$ and ${ }^{40} \mathrm{~K}$ radionuclides in water, soil and plants that reflect the latest environmental data in order to support environmental monitoring program from contamination of radioactivity around the Rembang Coal Power Plant. The sampling process, preparation and analysis based on the procedures of environmental radioactivity analysis. Natural radionuclides are measured by gamma spectrometry with HPGe detector was accredited by ISO 17025 in 2008. The result obtained showed that radioactivity in water ranges from $(0.90$ to 52.0$) \mathrm{mBq} / \mathrm{L}$, in soil ranges from (100.06 to 760.30) Bq/kg, while in cassava leaves ranges from (24.59 to 60.96) Bq/ $/ \mathrm{Kg}$. Based on PERKA BAPETEN. No 7 2017, the allowed limit of radioactivity in water ranges from (730 to 1000) $\mathrm{mBq} / \mathrm{L}$, while the results of the analysis of the water that found around the Rembang Coal Power Plant are still below the limit value permitted by BAPETEN.

Keywords : natural radioactivity, gamma spectrometry, water, soil and cassava leaves

\section{PENDAHULUAN}

Keberadaan PLTU batubara Rembang merupakan salah satu sumber yang berkontribusi sebagai penghasil radioaktivitas alam atau Naturally Occurring Radioactive Materials (NORM) dan Technologically-Enhanced Naturally Occuring Radioactive Material (TENORM) ke lingkungan yang berasal dari batubara sebagai bahan bakunya. Data dasar radioaktivitas lingkungan (baseline data) diperoleh peningkatan kandungan NORM dan 
TENORM di ambien daerah sekitar PLTU. Sehingga diperlukan monitoring keluaran radioaktif yang berasal dari batubara untuk melihat apakah ada peningkatan kandungan radioaktif yang ditimbulkan oleh PLTU $[1,2]$.

Proses pembakaran batubara pada unit pembangkit uap (boiler) menghasilkan dua jenis abu yaitu abu terbang (fly ash) dan abu dasar (bottom ash). Komposisi abu batubara yang dihasilkan terdiri dari $10-20 \%$ abu dasar dan sisanya sekitar $80-90 \%$ berupa abu layang. Abu akibat proses pembakaran batubara yang membawa zat-zat radioaktif dapat menempel atau menyatu dengan tanaman, tanah maupun air sehingga dapat mengganggu kualitas ekosistem pada lingkungan sekitar PLTU. Sifat tanaman mampu menyerap atau menampung debu atau abu yang berada di sekitar tanaman, termasuk abu hasil pembakaran batubara, sehingga dapat menyebarkan zat radioaktif ke organisme lainnya melalui rantai makanan. Air dapat melarutkan zat radiaktif dalam abu hasil pembakaran batubara ke lingkungan sekitar.Sedangkan abu yang terjatuh di tanah dan tercampur dengan tanah, memungkinkan adanya leaching zat radiaoktif dari abu ke tanah sekitar, sehingga kandungan zat radioaktif yang berasal dari hasil pembakaran batubara bisa berada di tanaman, air maupun tanah. [2-4].

Tujuan dari penelitian ini adalah, mengetahui distribusi konsentrasi aktivitas radionuklida alam ${ }^{226} \mathrm{Ra}$, ${ }^{228} \mathrm{Ra}$, ${ }^{232} \mathrm{Th}$ dan ${ }^{40} \mathrm{~K}-40$ dalam air, tanah dan tanaman yang mengakomodasi data lingkungan terkini dalam rangka mendukung program bersih pencemaran radioaktivitas di sekitar PLTU Rembang. Nilai aktivitas radionuklida alam pada sampel tanah, air dan tanaman di sekitar PLTU Rembang pada penelitian ini akan dibandingkan dengan nilai baku mutu radioaktifitas lingkungan yang ditetapkan oleh BAPETEN. Manfaat dari penelitian ini adalah memberikan informasi bagi masyarakat terkait dalam melakukan pemantauan lingkungan hidup di sekitar PLTU Rembang serta memberikan tambahan data dalam penelitian yang terkait peningkatan radioaktivitas lingkungan sekitar PLTU Rembang.

\section{METODOLOGI}

\section{Lokasi sampling}

Pengambilan cuplikan dilakukan pada 6 (enam) lokasi di Kecamatan Sluke kabupaten Rembang bagian tengah pada musim kemarau yaitu tanggal 26 Juli sampai 3 Agustus 2016. Lokasi sampling disajikan dalam Tabel 1.

Tabel 1. Lokasi Sampling Udara Ambien di Sekitar PLTU Rembang

\begin{tabular}{ccc}
\hline Lokasi & Koordinat GPS & $\begin{array}{c}\text { Keterangan jarak dari } \\
\text { cerobong PLTU }\end{array}$ \\
\hline 1 & $06^{\circ} 38^{\prime} 03,20^{\prime \prime} \mathrm{LS}, 111^{\circ} 29^{\prime} 10,85^{\prime \prime} \mathrm{BT}$ & $1,2 \mathrm{~km}$ \\
2 & $06^{\circ} 37^{\prime} 53,10^{\prime \prime} \mathrm{LS}, 111^{\circ} 29^{\prime} 08,70^{\prime \prime} \mathrm{BT}$ & $2,1 \mathrm{~km}$ \\
3 & $06^{\circ} 37^{\prime} 53,10^{\prime \prime} \mathrm{LS}, 111^{\circ} 29^{\prime} 08,70^{\prime \prime} \mathrm{BT}$ & $1,3 \mathrm{~km}$ \\
4 & $06^{\circ} 37^{\prime} 47,30^{\prime \prime} \mathrm{LS}, 111^{\circ} 29^{\prime} 41,30^{\prime \prime} \mathrm{BT}$ & $2,3 \mathrm{~km}$ \\
5 & $06^{\circ} 37^{\prime} 41,90^{\prime \prime} \mathrm{LS}, 111^{\circ} 29^{\prime} 05,20^{\prime \prime} \mathrm{BT}$ & $1,3 \mathrm{~km}$ \\
6 & $06^{\circ} 37^{\prime} 33,00^{\prime \prime} \mathrm{LS}, 111^{\circ} 29^{\prime} 39,60^{\prime \prime} \mathrm{BT}$ & $2,3 \mathrm{~km}$ \\
\hline
\end{tabular}

\section{Bahan}

Bahan yang digunakan dalam penelitian ini adalah tanah, air sumur dan daun singkong yang diambil pada 6 lokasi sampling.Pengambilan sampel tanah dilakukan dengan kedalaman 0-10 cm dan dipilih lokasi yang diperkirakan tidak terlalu terpengaruh oleh pupuk dari aktivitas pertanian. Standar analisis yang digunakan adalah Standard Reference Material IAEA-315 Radionuclides in Marine Sediment dan NIST SRM 4359 Seaweed Radionuclide Standard.

\section{Alat yang digunakan}

Alat yang digunakan pada penelitian ini antara lain seperangkat alat spektrometer y yang dilengkapi dengan detektor semikonduktor HPGe dan software Genie 2000, botol polyethelene yang dapat diseal untuk 
menyimpan tanah dan tanaman agar kedap udara, alat GPS (Global Positioning System) Garmin untuk mengukur posisi titik pengukuran, alat homogenisasi untuk menghomogenkan sampel serbuk, sekop untuk mengambil sampel tanah dan jerigen untuk tempat sampel air.

\section{Cara kerja}

Sampel tanah yang telah kering dibersihkan dari kotoran dan dihaluskan hingga lolos 100 mesh. Begitu juga dengan sampel tanaman yang perlu diangin-anginkan hingga kering dan dihaluskan serta diayak hingga lolos ukuran 100 mesh. Sampel tanah dan tanaman perlu dihomogenkan menggunakan alat homogenisasi selama 6 jam dengan kecepatan 290 rpm. Sampel tanah dan tanaman masing-masing ditimbang sebanyak 70 gram dan ditempatkan dalam botol polyethelene (diameter $48 \mathrm{~mm}$ dan tinggi $50 \mathrm{~mm}$ ) yang berlabel dan disegel $[5,7]$. Khusus sampel air, sebanyak $1000 \mathrm{ml}$ diuapkan secara pelan-pelan dalam cawan porselin di atas pemanas sampai sisanya air tertinggal $20 \mathrm{ml}$ dan dimasukkan ke dalam botol polyethelene.

Analisis sampel dilakukan menggunakan spektrometer gamma dilengkapi dengan software Genie 2000 dan detektor HPGe.Penentuan performa detektor dilakukan dengan menggunakan point source pada penentuan efisiensi detektor jarak tertentu $[3,5,6]$. Pengukuran radioaktivitas ${ }^{226} \mathrm{Ra},{ }^{238} \mathrm{U}$ dan ${ }^{232} \mathrm{Th}$ dilakukan dari radioaktivitas anak luruhnya terutama radon. Hal ini didasarkan asumsi bahwa telah terjadi kesetimbangan sekular setelah sampel dalam kondisi kedap udara selama 30 hari $[3,4,6]$ dan dapat juga kesetimbangan sekular setelah 21 hari $[7,8]$. Kesetimbangan sekular terjadi pada peluruhan radionuklida dengan umur paruh yang jauh lebih panjang dibandingkan radionuklida anak luruhnya. Radionuklida alam yang ditentukan aktivitasnya pada penelitian ini adalah ${ }^{210} \mathrm{~Pb}(46,5 \mathrm{keV}),{ }^{234} \mathrm{Th}(63,0 \mathrm{keV}),{ }^{235} \mathrm{U}(143,8$ dan $185,7 \mathrm{keV}),{ }^{214} \mathrm{~Pb}(295,6 ; 351,9 \mathrm{keV})$, ${ }^{214} \mathrm{Bi}(609,3,1120,3$, dan $1764,5 \mathrm{keV}),{ }^{228} \mathrm{Ac}$ (338,6 dan 911,1 kev) dan ${ }^{40} \mathrm{~K}(1460,7 \mathrm{keV})$. Khusus ${ }^{210} \mathrm{~Pb}$ dan ${ }^{234} \mathrm{Th}$ mempunyai energi karakteristik rendah sehingga penentuan radioaktivitas menggunakan metode komparatif terhadap SRM yang mempunyai energi gamma rendah.

\section{Penentuan radionuklida induk}

Dari pengukuran sampel didapatkan beberapa radionuklida ${ }^{212} \mathrm{~Pb},{ }^{214} \mathrm{~Pb},{ }^{208} \mathrm{TI},{ }^{214} \mathrm{Bi},{ }^{228} \mathrm{Ac}$ yang merupakan anak-anak luruh dari radionuklida deret uranium dan thorium serta radionuklida ${ }^{40} \mathrm{~K}$. Untuk identifikasi ${ }^{226} \mathrm{Ra}$ melalui anak luruhnya yaitu radionuklida ${ }^{214} \mathrm{Bi}(609,3 ; 1120,3$ dan $1764,5 \mathrm{keV})$ dan Th-232 melalui anak luruhnya yaitu ${ }^{214} \mathrm{~Pb}(295,6 ; 351,9 \mathrm{keV})$ dan Ac-228 (338,6 dan 911,1 kev).

\section{HASIL DAN PEMBAHASAN}

Penelitian ini bertujuan untuk menentukan aktivitas radionuklida alami yang terkandung pada sampel tanah, tanaman (daun singkong) dan air yang diambil pada daerah di sekitar PLTU Rembang.Pengukuran dilakukan menggunakan teknik spektrometri sinar gamma di laboratorium Radiokimia PSTA-BATAN Yogyakarta.

Penentuan aktivitas radionuklida dilakukan dengan menganalisis data spektrum latar dan sampel air, tanah dan tanaman. Analisis sampel menggunakan Software Genie 2000dan Microsoft Excel 2016 sehingga diperoleh nilai kualitatif dan kuantitaif radionuklida alam, yang disajikan pada Tabel 2.

Pada Tabel 2 dapat diketahui bahwa aktivitas radionuklida pada sampel tanah yang tertinggi adalah radionuklida ${ }^{40} \mathrm{~K}$ pada lokasi 1 dan 6 , sedangkan radionuklida terrendah adalah $235 \mathrm{U}$ terdapat pada lokasi 3.

Rerata konsentrasi untuk ${ }^{232} \mathrm{Th}(8,49 \mathrm{~Bq} / \mathrm{kg})$ yang dianalisis dalam penelitian ini ternyata $18 \%$ lebih rendah dibanding rerata aktivitas ${ }^{232} \mathrm{Th}$ di tanah nilai rerata diberbagai Negara (meliputi Malaysia, China, Mesir, Algeria, India, Portugal, Hongkong, USA dan Tanzania) yaitu sebesar 48,2 Bq/kg dan rerata di dunia adalah 35 $\mathrm{Bq} / \mathrm{kg}$ [9]. Rerata konsentrasi untuk ${ }^{40 \mathrm{~K}}(301,9 \mathrm{Bg} / \mathrm{Kg})$ yang pada penelitian ini lebih rendah nilai rerata di dunia $(400 \mathrm{Bg} / \mathrm{Kg}$ ) dan lebih rendah $66,44 \%$ dari rerata konsentrasi diberbagai Negara (meliputi Malaysia, China, Mesir, Algeria, India, Portugal, Hongkong, USA dan Tanzania) yaitu sebesar 454,4 Bq/Kg [9]. Pada penelitian ini, nilai rerata ${ }^{40} \mathrm{~K}$ tertinggi terdapat pada sampel lokasi 1 dan 6 dengan konsentrasi 460,3 Bq/kg di Dusun Trahan, Desa Trahan yang berjarak 1,2 km dari cerobong PLTU dan Dusun Krajan, Desa Pangkalan, yang berjarak 2,3 km dari cerobang PLTU Rembang. 
Tabel 2. Aktivitas Radionuklida Sampel Tanah

\begin{tabular}{ccccccc}
\hline \multirow{2}{*}{ Radionuklida } & \multicolumn{7}{c}{ Aktivitas $(\mathrm{Bq} / \mathrm{Kg})$} \\
\cline { 2 - 6 } & Lokasi 1 & Lokasi 2 & Lokasi 3 & Lokasi 4 & Lokasi 5 & Lokasi 6 \\
\hline${ }^{226} \mathrm{Ra}$ & 9,41 & 6,86 & 10,41 & 4,77 & 10,98 & 9,41 \\
${ }^{228} \mathrm{Ra}$ & 11,41 & 7,57 & 13,02 & 6,21 & 12,89 & 11,41 \\
${ }^{232} \mathrm{Th}$ & 9,26 & 6,36 & 10,39 & 5,89 & 9,78 & 9,26 \\
$40 \mathrm{~K}$ & 460,30 & 180,51 & 270,48 & 100,06 & 340,07 & 460,30 \\
${ }^{210} \mathrm{~Pb}$ & 15,395 & 7,168 & 14,524 & 8,642 & 6,311 & 5,203 \\
${ }^{235} \mathrm{U}$ & 0,0183 & 0,0113 & 0,0094 & 0,0208 & 0,0124 & 0,0101 \\
\hline
\end{tabular}

Pada Tabel 3 tersaji aktivitas radionuklida pada sampel tanaman berupa daun singkong.Terdeteksi 4 radionuklida yaitu ${ }^{226} \mathrm{Ra},{ }^{228} \mathrm{Ra},{ }^{232} \mathrm{Th}$ dan ${ }^{40} \mathrm{~K}$. Dari keempat radionuklida terdeteksi, radionuklida ${ }^{40} \mathrm{~K}$ mempunyai konsentrasi tertinggi di lokasi 3 dan radionuklida terendah terdapat pada lokasi 5 yaitu radionuklida ${ }^{232} \mathrm{Th}$.

$\mathrm{Di}$ India daun tanaman obat mempunyai konsentrasi untuk radionuklida ${ }^{226} \mathrm{Ra}$ bervariasi 2,66 sampai $11,27 \mathrm{~Bq} / \mathrm{kg}$ dengan nilai rerata $6,34 \mathrm{~Bq} / \mathrm{kg}$. Sedangkan aktivitas ${ }^{232} \mathrm{Th}$ yang terdetekisi pada sampel dalam penelitian ini berkisar antara 2,42 sampai 8,72 Bq/kg dengan nilai rerata $5 \pm 0,71 \mathrm{~Bq} / \mathrm{kg}$ [10]. Di Nigeria rerata aktivitas ${ }^{40} \mathrm{~K}$ pada tanaman yaitu $171,72 \mathrm{~Bq} / \mathrm{Kg}$, $226 \mathrm{Ra} 25,02 \mathrm{~Bq} / \mathrm{Kg}$ dan ${ }^{232} \mathrm{Th} 35,09 \mathrm{~Bq} / \mathrm{Kg}$. Aktivitas radionuklida alam yang terserap oleh tubuh karena konsumsi tanaman yang mengandung ${ }^{226} \mathrm{Ra},{ }^{232} \mathrm{Th}$ dan ${ }^{40} \mathrm{~K}$ setara dengan nilai rerata dosis efektif tahunan yaitu $0,00538 \mathrm{mSv} /$ tahun. Dalam hal ini masih di bawah rerata dosis efektif tahunan di seluruh dunia yaitu 0,3 mSv/tahun yang diberikan dalam laporan UNSCEAR 2000 [11]. Aktivitas yang terukur pada daun singkong di sekitar PLTU Rembang di 6 lokasi sampling, radionuklida ${ }^{226} \mathrm{Ra}$, ${ }^{232} \mathrm{Th}$ dan ${ }^{40} \mathrm{~K}$ mempunyai aktivitas rerata tertinggi berturut-turut adalah $0,62 \mathrm{~Bq} / \mathrm{Kg}, 0,27 \mathrm{~Bq} / \mathrm{Kg}$ dan $60,69 \mathrm{~Bq} / \mathrm{Kg}$, dan masih jauh dibawah laporan UNSCEAR 2000.

Tabel 3. Aktivitas Radionuklida Sampel Tanaman

\begin{tabular}{ccccccc}
\hline \multirow{2}{*}{ Radionuklida } & \multicolumn{6}{c}{ Aktivitas (Bq/Kg) } \\
\cline { 2 - 7 } & Lokasi 1 & Lokasi 2 & Lokasi 3 & Lokasi 4 & Lokasi 5 & Lokasi 6 \\
\hline${ }^{226} \mathrm{Ra}$ & 0,62 & 0,43 & 0,50 & 0,50 & 0,38 & 0,29 \\
${ }^{228} \mathrm{Ra}$ & 1,00 & 0,74 & 0,63 & 0,77 & 0,87 & 1,12 \\
${ }^{232} \mathrm{Th}$ & 0,21 & 0,27 & 0,20 & 0,19 & 0,17 & 0,20 \\
${ }^{40 \mathrm{~K}}$ & 42,99 & 49,09 & 60,96 & 35,01 & 24,59 & 37,31 \\
\hline
\end{tabular}

Kegiatan industri, domestik dan kegiatan lainnya akan berdampak negatif terhadap sumber daya air, termasuk pernurunan kualitas air. kondisi ini dapat menimbulkan gangguan, kerusakan dan bahaya bagi makluk hidup yang bergantung pada sumber daya air [12]. Radionuklida dalam air secara alami terdapat dalam lingkungan, akan tetapi aktivitas manusia dapat meningkatkan kandungan radionuklida dalam lingkungan, misalnya ada aktivitas pembakaran batubara. Radioaktivitas yang terdapat dalam air lingkungan disajikan pada Tabel 4 dengan aktivitas yang berbeda-beda tiap lokasi. Seperti halnya pada tanah maupun tanaman, pada air lingkungan aktivitas radionuklida ${ }^{40} \mathrm{~K}$ juga merupakan radioaktivitas yang tertinggi yaitu berkisar $0,0004 \mathrm{~Bq} / \mathrm{L}$ sampai $0,0525 \mathrm{~Bq} / \mathrm{L}$, atau $(0,40-52,50) \mathrm{Bq} / \mathrm{m}^{3}$.

Aktivitas ${ }^{226} \mathrm{Ra}$, ${ }^{228} \mathrm{Ra}$ dan ${ }^{40 \mathrm{~K}}$ diukur dalam sampel air minum di Turki berturut-turut adalah $27-2431$ $\mathrm{mBq} / \mathrm{L}, 36-270 \mathrm{mBq} / \mathrm{L}$ dan $47-2880 \mathrm{mBq} / \mathrm{L} \mathrm{[13]}$. Air sungai di negara Tanzania untuk radionuklida ${ }^{232} \mathrm{Th}$ dan ${ }^{40} \mathrm{~K}$ masing-masing mempunyai konsentrasi aktivitas adalah $1,8 \mathrm{~Bq} / \mathrm{L}$ dan $9,2 \mathrm{~Bq} / \mathrm{L}[9]$.

Menurut PERKA BAPETEN. No 7 Tahun 2013. Tentang Nilai Batas Radioaktivitas Lingkungan, untuk radionuklida Th-232 adalah $730 \mathrm{~Bq} / \mathrm{m}^{3}$ dan radionuklida Ra-226 adalah $1000 \mathrm{~Bq} / \mathrm{m}^{3}$ dalam air [14]. Sehingga hasil analisis pengukuran air yang terdapat disekitar PLTU Rembang dalam radius 1,0-2,0 km masih dibawah nilai batas yang diijinkan oleh BAPETEN. 
Tabel 4. Aktivitas Radionuklida Sampel Air

\begin{tabular}{ccccccc}
\hline \multirow{2}{*}{ Radionuklida } & \multicolumn{6}{c}{ Aktivitas $(\mathrm{Bq} / \mathrm{L})$} \\
\cline { 2 - 7 } & Lokasi 1 & Lokasi 2 & Lokasi 3 & Lokasi 4 & Lokasi 5 & Lokasi 6 \\
\hline${ }^{226} \mathrm{Ra}$ & 0,0032 & 0,0041 & 0,0036 & 0,0024 & 0,0035 & 0,0037 \\
${ }^{228} \mathrm{Ra}$ & 0,0037 & 0,0034 & 0,0063 & 0,0065 & 0,0025 & 0,0049 \\
${ }^{232} \mathrm{Th}$ & 0,0011 & 0,0009 & 0,0008 & 0,0007 & 0,0007 & 0,0004 \\
${ }^{40 \mathrm{~K}}$ & 0,0212 & 0,0307 & 0,0456 & 0,0311 & 0,0171 & 0,0525 \\
\hline
\end{tabular}

\section{Distribusi Aktivitas Radionuklida}

Distribusi aktivitas ${ }^{226} \mathrm{Ra},{ }^{228} \mathrm{Ra}$, ${ }^{232} \mathrm{Th}$, dan ${ }^{40} \mathrm{~K}$ didapatkan dari pengolahan data kuantitatif analisis sampel yang digabungkan dengan data pendukung berupa data koordinat GPS lokasi pengambilan sampel menjadi peta kontur yang diolah menggunakan software Surfer12. Terdapat 6 lokasi pengambilan sampel dengan variasi jarak dan sudut antar lokasi serta dengan pengambilan sampel air, tanah dan tanaman (daun singkong).

\section{Distribusi aktivitas ${ }^{226} \mathrm{Ra}$}

Distribusi aktivitas ${ }^{226}$ Ra pada sampel tanah dapat dilihat pada peta kontur Gambar 1a. Pola sebaran aktivitas ${ }^{226}$ Ra pada sampel tanah terbesar berada pada lokasi 5 disusul lokasi 3, 1, 6, 2 dan 4. Selisih secara kuantitatif antara lokasi tersebut berada pada skala ratusan mikro becquerel per kilogram dimana aktivitas ${ }^{226} \mathrm{Ra}$ sangat terpusat di lokasi 5 yang berjarak $1,3 \mathrm{~km}$ dan bersudut $\pm 45^{0}$ dari cerobong PLTU Rembang. Kuantitas aktivitas ${ }^{228}$ Ra semakin menurun ke arah utara pada sudut $\pm 68^{\circ}$ hingga sudut $\pm 45^{\circ}$

Pola distribusi ${ }^{226}$ Ra pada sampel air sedikit berbeda jika dibandingkan dengan sampel tanah.Gambar 1b.menunjukkan justru lokasi 2 memiliki aktivitas ${ }^{226}$ Ra paling besar yang disusul lokasi $6,3,5,1$ dan 4 . Selisih aktivitas ${ }^{226}$ Ra pada tiap lokasi berkisar pada skala puluhan. Jika pada sampel tanah aktivitas ${ }^{226}$ Ra paling besar pada lokasi 5 maka dalam sampel air menunjukkan hal yang berbeda.

Pola distribusi yang berbeda juga ditunjukkan oleh aktivitas ${ }^{226}$ Ra sampel tanaman.Dalam skala yang jauh lebih kecil perbedaan antar lokasi pengambilan sampel, pola distribusi terlihat pada Gambar 1c.Pada Gambar 1c menunjukkan lokasi 1 memiliki aktivitas ${ }^{226}$ Ra paling besar disusul lokasi 3, 4, 2, 5, dan 6.Selisih dari konsentrasi aktivitas ${ }^{226}$ Ra pada tiap lokasi berkisar pada skala puluhan.
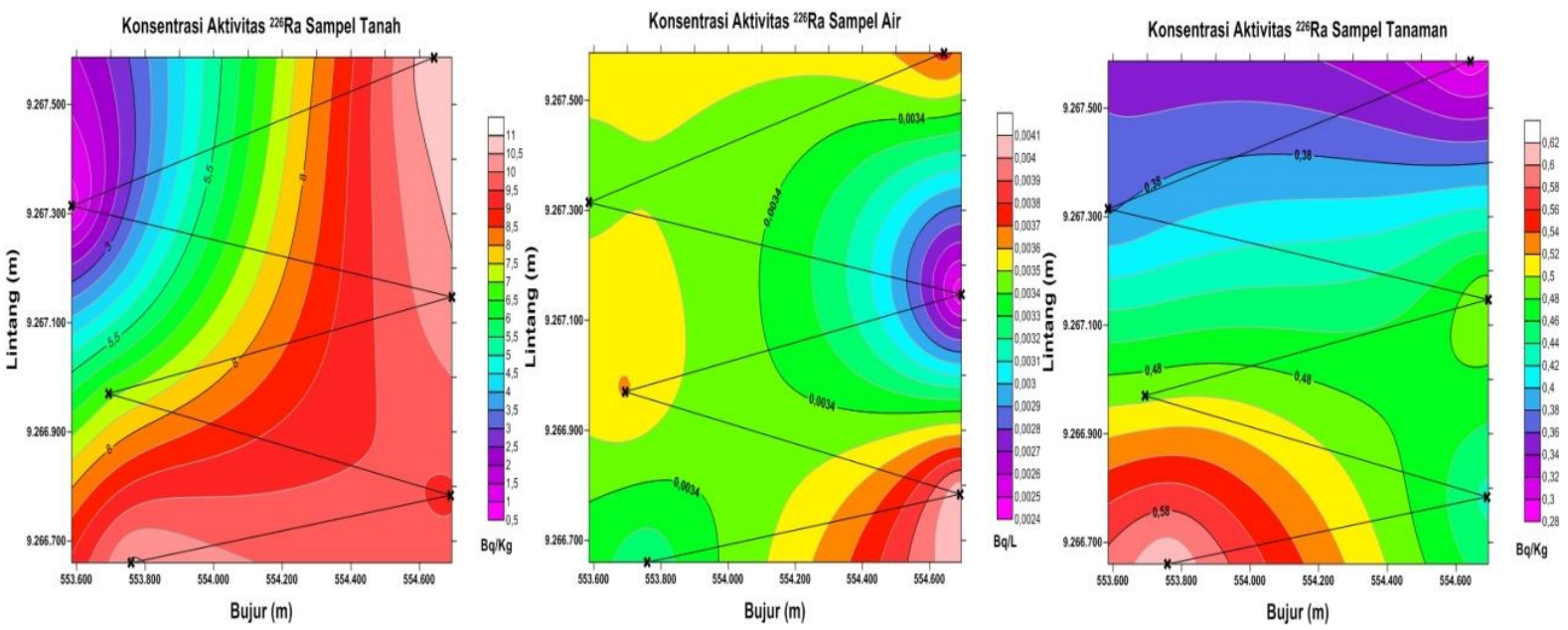

Gambar 1. Distribusi ${ }^{226}$ Ra pada sampel (a) tanah, (b) air dan (c) tanaman 


\section{Distribusi aktivitas ${ }^{228} \mathrm{Ra}$}

Pola distribusi aktivitas ${ }^{228} \mathrm{Ra}$ pada sampel tanah dapat dilihat pada Gambar 2a.Aktivitas ${ }^{228} \mathrm{Ra}$ pada sampel tanah terbesar berada pada lokasi 3 disusul lokasi 5,6,1,2 dan lokasi 4. Radionuklida ${ }^{228}$ Ra sangat terpusat di lokasi 6 yang berjarak $2,3 \mathrm{~km}$ dan bersudut $\pm 45^{\circ}$ dari cerobong PLTU Rembang. Kuantitas aktivitas ${ }^{228} \mathrm{Ra}$ semakin menurun ke arah utara pada sudut $\pm 68^{\circ}$ hingga sudut $\pm 45^{\circ}$.

Hal sedikit berbeda ditunjukkan pola distribusi aktivitas ${ }^{228}$ Ra dalam sampel air. Pola distribusi aktivitas ${ }^{228} \mathrm{Ra}$ sampel air yang digambarkan pada Gambar $2 \mathrm{~b}$ menunjukkan justru lokasi 4 memiliki aktivitas ${ }^{228} \mathrm{Ra}$ paling besar disusul lokasi 3, 6, 1,2 dan 5 . Selisih dari aktivitas ${ }^{228}$ Ra pada tiap lokasi berkisar pada skala puluhan.Jika pada sampel tanah aktivitas ${ }^{228}$ Ra paling besar pada lokasi 6 maka dalam sampel air menunjukkan pola distribusi yang berbeda.

Pola distribusi yang berbeda juga ditunjukkan oleh aktivitas ${ }^{228}$ Ra sampel tanaman. Dalam skala yang jauh lebih kecil perbedaan antar lokasi pengambilan sampel, pola distribusi tersebut dijelaskan pada Gambar 2c menunjukkan justru lokasi 6 memiliki aktivitas ${ }^{228}$ Ra paling besar disusul lokasi 1, 5, 4, 2, dan 3 . Selisih dari aktivitas ${ }^{228}$ Ra pada tiap lokasi berkisar pada skala puluhan.
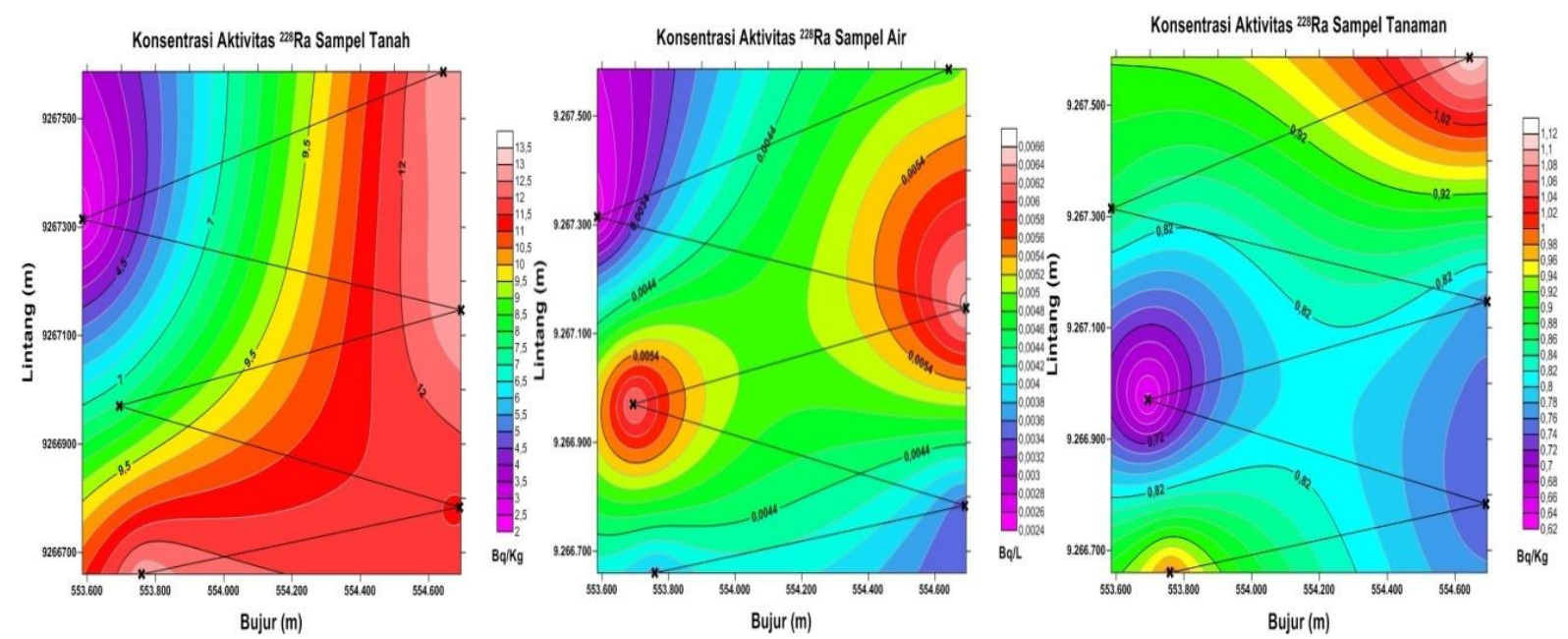

Gambar 2. Distribusi ${ }^{228}$ Ra pada sampel (a) tanah, (b) air dan (c) tanaman

\section{Distribusi aktivitas ${ }^{232} \mathrm{Th}$}

Distribusi aktivitas ${ }^{232} \mathrm{Th}$ pada sampel tanah dapat digambarkan oleh peta kontur Gambar 3a dimana aktivitas ${ }^{232}$ Th pada sampel tanah terbesar berada pada lokasi 4 disusul lokasi 1, 6, 2, 3 dan lokasi 5. Selisih secara kuantitatif antara lokasi tersebut berada pada skala ratusan mikro becquerel per meter kubiknya.Aktivitas ${ }^{232}$ Th sangat terpusat di lokasi 6 yang berjarak 2,3 km dan bersudut $\pm 45^{\circ}$ dari cerobong PLTU Rembang. Hal tersebut dimungkinkan karena jika dibandingkan dengan lokasi lainnnya lokasi 6 merupakan lokasi pengambilan sampel yang searah dengan arah angin dominan dari cerobong.Kuantitas aktivitas ${ }^{232}$ Th semakin menurun ke arah utara pada sudut $\pm 68^{\circ}$ hingga sudut $\pm 45^{\circ}$.

Pola distribusi aktivitas ${ }^{232}$ Th pada sampel air menunjukkan berbeda jika dibandingkan dengan pola distribusi pada sampel tanah. Pola distribusi aktivitas ${ }^{232}$ Th sampel air yang digambarkan pada Gambar $3 b$ menunjukkan justru lokasi 1 memiliki aktivitas ${ }^{232}$ Th paling besar disusul lokasi 2, 3, 5, 4, dan lokasi 6. Selisih dari aktivitas ${ }^{232} \mathrm{Th}$ pada tiap lokasi berkisar pada skala puluhan. Jika pada sampel tanah aktivitas ${ }^{232} \mathrm{Th}$ paling besar pada lokasi 1 maka dalam sampel air menunjukkan pola distribusi yang berbeda.

Pola distribusi yang berbeda juga ditunjukkan oleh aktivitas ${ }^{232} \mathrm{Th}$ pada sampel tanaman. Dalam skala yang jauh lebih kecil perbedaan antar lokasi pengambilan sampel, pola distribusi tersebut dijelaskan pada Gambar 3c dimana menunjukkan bahwa lokasi 2 memiliki aktivitas ${ }^{232}$ Th paling besar disusul lokasi 1, 6, 3, 4, dan 
5. Selisih dari aktivitas ${ }^{232}$ Th pada tiap lokasi berkisar pada skala puluhan.Jika pada sampel tanah aktivitas ${ }^{232} \mathrm{Th}$ paling besar pada lokasi 1 maka dalam sampel tanaman menunjukkan pola distribusi yang berbeda.
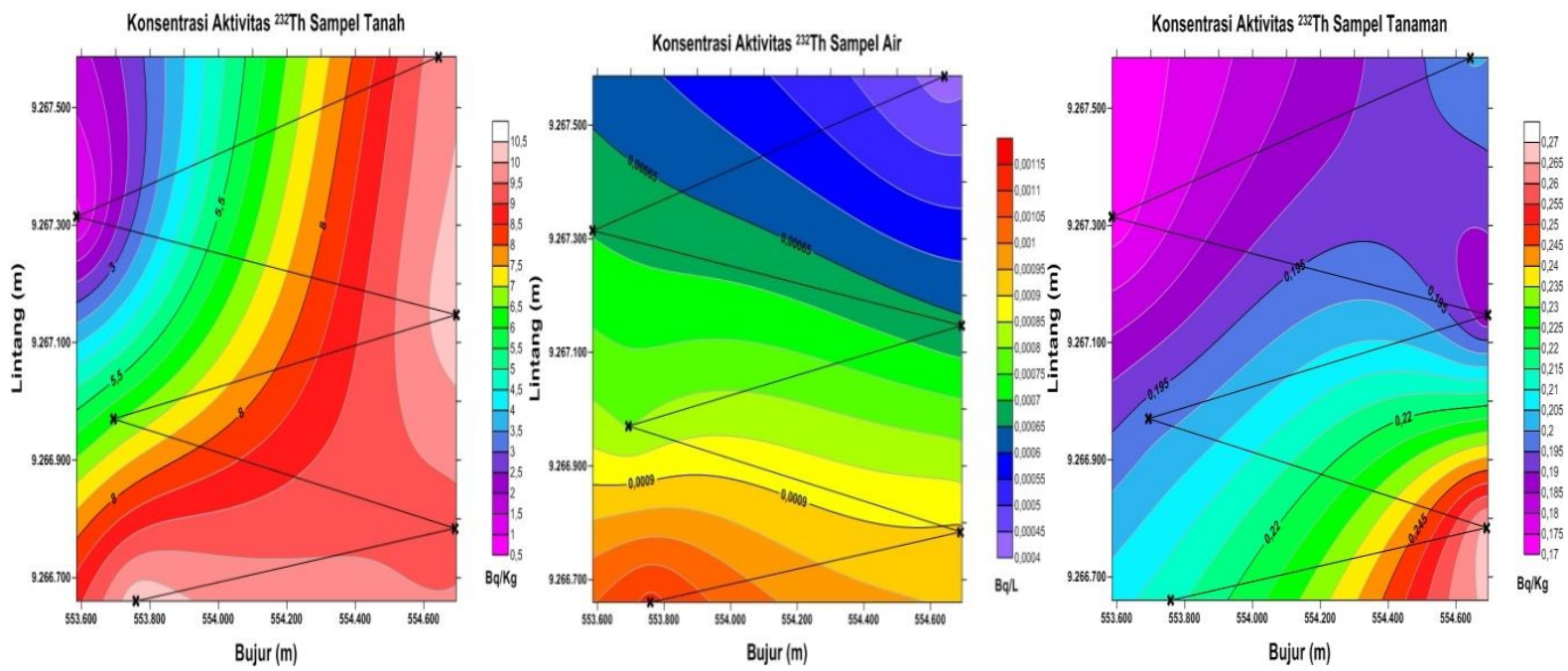

Gambar 3. Distribusi ${ }^{232}$ Th pada sampel (a) tanah, (b) air dan (c) tanaman

\section{Distribusi aktivitas ${ }^{40} \mathrm{~K}$}

Distribusi aktivitas ${ }^{40} \mathrm{~K}$ pada sampel tanah dapat digambarkan oleh peta kontur Gambar $4 \mathrm{a}$ yang menunjukkan bahwa aktivitas ${ }^{40} \mathrm{~K}$ pada sampel tanah terbesar berada pada lokasi 2 disusul lokasi $6,1,4,3$ dan 5. Selisih secara kuantitatif antara lokasi tersebut berada pada skala ratusan mikro becquerel per meter kubiknya dimana aktivitas ${ }^{40} \mathrm{~K}$ sangat terpusat di lokasi 6 yang berjarak $2,3 \mathrm{~km}$ dan bersudut $\pm 45^{\circ}$ dari cerobong PLTU Rembang. Hal tersebut dimungkinkan karena jika dibandingkan dengan lokasi lainnnya lokasi 6 merupakan lokasi pengambilan sampel yang searah dengan arah angin dominan dari cerobong.Kuantitas aktivitas ${ }^{40} \mathrm{~K}$ semakin menurun ke arah utara pada sudut $\pm 68^{\circ}$ hingga sudut $\pm 45^{\circ}$.
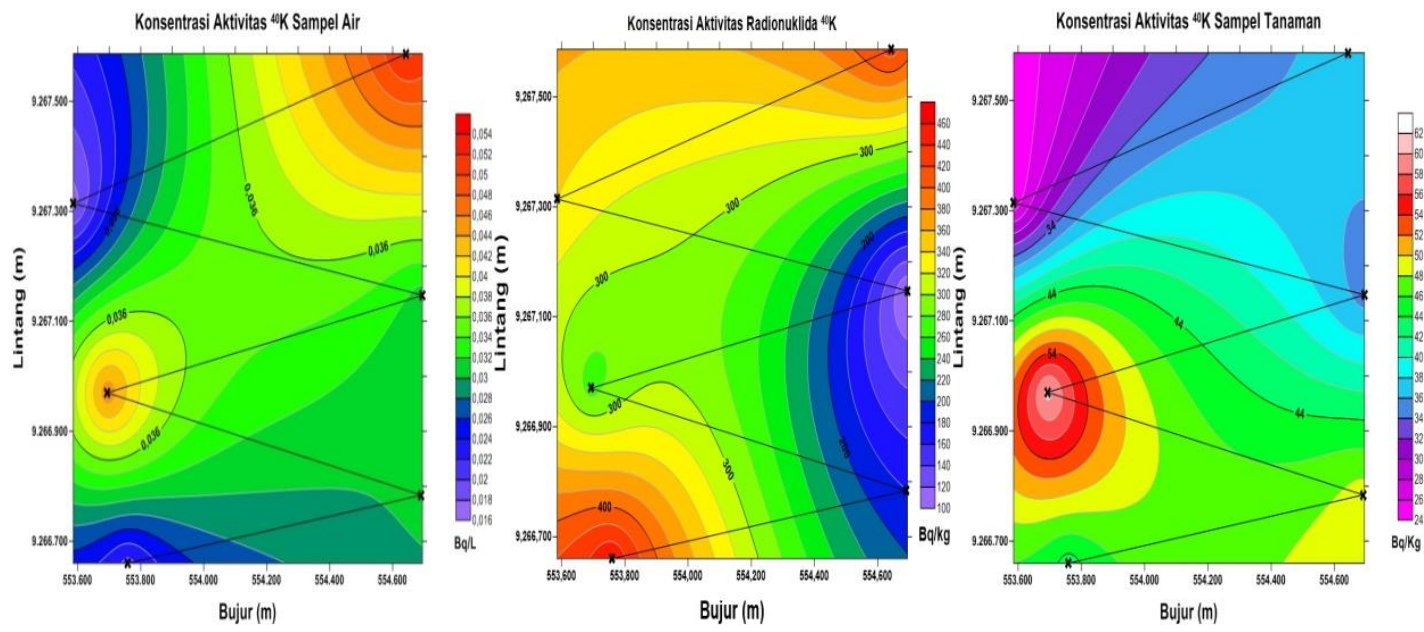

Gambar 4. Distribusi ${ }^{40} \mathrm{~K}$ pada sampel (a) tanah, (b) air dan (c) tanaman

Hal berbeda ditunjukkan Gambar 4b dimana distribusi aktivitas ${ }^{40} \mathrm{~K}$ pada sampel air menunjukkan perbedaan pola distribusi seperti pada sampel tanah. Pola distribusi aktivitas ${ }^{40} \mathrm{~K}$ sampel air menunjukkan lokasi 6 memiliki aktivitas ${ }^{40} \mathrm{~K}$ paling besar disusul lokasi 3, 4, 2, 1, dan lokasi 5 . Selisih dari aktivitas ${ }^{40} \mathrm{~K}$ pada tiap 
lokasi berkisar pada skala puluhan. Jika pada sampel tanah aktivitas ${ }^{40} \mathrm{~K}$ paling besar pada lokasi 1 maka dalam sampel air menunjukkan pola distribusi yang berbeda.

Pola distribusi yang berbeda juga ditunjukkan oleh aktivitas ${ }^{40} \mathrm{~K}$ dalam sampel tanaman. Dalam skala yang jauh lebih kecil perbedaan antar lokasi pengambilan sampel, pola distribusi ${ }^{40} \mathrm{~K}$ dalam tanaman disajikan pada Gambar 4c dimana lokasi 6 memiliki aktivitas ${ }^{40} \mathrm{~K}$ paling besar disusul lokasi 1, 5, 4, 3, dan 2. Selisih dari aktivitas ${ }^{40} \mathrm{~K}$ pada tiap lokasi berkisar pada skala puluhan. Jika pada sampel tanah aktivitas ${ }^{40} \mathrm{~K}$ paling besar pada lokasi 1 maka dalam sampel tanaman menunjukkan pola distribusi yang berbeda.

\section{KESIMPULAN}

Radionuklida alam terdistribusi terbesar dominan berada di titik lokasi yang lebih dekat dari cerobong PLTU, yaitu di titik 1, 3 dan 5 yang berjarak sekitar $1 \mathrm{~km}$ dari cerobong PLTU, sedangkan lokasi 2, 4 dan 6 yang berjarak sekitar $2 \mathrm{~km}$ cenderung lebih kecil aktivitasi radionuklida alamnya. Sehingga dapat dikatakan bahwa faktor jauh dan dekat dari cerobang PLTU berpengaruh dalam penyebaran radionuklida alam.Menurut PERKA BAPETEN. No 7 Tahun 2013 tentang Nilai Batas Radioaktivitas Lingkungan $(730-1000) \mathrm{mBq} / \mathrm{L}$, hasil analisis pengukuran air yang terdapat disekitar PLTU Rembang masih dibawah nilai batas berkisar $(0,90-52,0) \mathrm{mBq} / \mathrm{L}$ dibawah batas yang diijinkan oleh BAPETEN.

\section{Ucapan terima kasih}

Penulis mengucapkan terima kasih pada Dr. Susilo Widodo dan Ir. Moch.Setyadji, MT selaku pembina penelitian.Penulis juga mengucapkan terima kasih kepada Prof. Dr. Ir. Agus Taftazani selaku penanggung jawab SIPL penelitian di kelompok Teknik Analisis Nuklir dan Kimia.

\section{DAFTAR PUSTAKA}

[1]. LAURER.N.E., JAMES C.H., HEILEEN. H.K., ROSS. K.T., Naturally Occuring Radioactive Materials in Coals and Coal Combustion Residuals in the United States, American Chemical Society, 2015.

[2]. PANDIT.G.G, SAHU.S.K, PURANIK. V.D.,Natural radionuclides from coal fired thermal power plants estimation of atmospheric release and inhalation risk, Radioprotection, vol 46. EDP Sciences, p. 173-179, 2011.

[3]. SUKIRNO., SRI MURNIASIH. SUTANTO. W.W. Radioaktivitas Alam Hasil Pembakaran Batubara dari PLTU Pacitan. Prosiding. PPI-PDITN. PSTA BATAN Yogyakarta, 2016

[4]. MICHALIK B., NORM contaminated area identification using radionuclides activity concentration pattern in a soil profile, Journal of Environmental Radioactivity, Vol. 173, p. 102-111, 2017.

[5]. OZDEN B., GULER E., VAASMAT., HORVATH M., M., KOVACST., Enrichment of naturally occurring radionuclides and trace elements in Yatagan and Yenikoy coal-fired thermal power plants, Turkey, Journal of Environmental Radioactivity, Vol. 188, p. 100-107, 2018.

[6]. Larionova N.V., Lukashenko S.N., Kabdyrakova A.M., Kunduzbayeva A.Ye., Ivanova A.R., Transfer of Radionuclides to Plants of Natural Ecosystems at The Semipalatinsk Test Site, Journal of Environmental Radioactivity, Vol. 186, p. 63-70, 2018

[7]. HAQUE M., FERDOUS M. J., Transfer of natural radionuclidesfrom soil to plants in SavarDhaka, Spanish Journal of Soil Science, Vol. 7(2) p. 133 -145,2017

[8]. RAGHU Y., RAVISANKAR R., CHANDRASEKARAN A., VIJAYAGOPAL P., VENKATRAMAN B., Assessment of natural radioactivity and radiological hazards in building materials used in the Tiruvannamalai District, Tamilnadu, India, using a statistical approach, Journal of Taibah University for Science 11, p. 523-533, 2017

[9]. RAVISANKAR R., RAGHU Y., CHANDRASEKARAN Y., SURESH GANDHI M., VIJAYAGOPAL P., VENKATRAMAN B., Determination of natural radioactivity and the associated radiation hazards in building 
materials used in Polur, Tiruvannamalai District, Tamilnadu, India using gamma ray spectrometry with statistical approach, Journal of Environmental Radioactivity, Vol. 163, p. 41-52, 2016

[10]. CHANDRASHEKARA K., SOMASHEKARAPPA. H.M., Estimation of Radionuclides Roncentration and Rverage Annual Committed Effective Dose due to Ingestion for some Selected Medicinal Plants of South India. Journal of Radiation Research and Applied. Sciences, p. 68-77, 2016

[11]. NJINGA.R L., JONAH S.A., GOMIN A.M., Preliminary investigation of naturally occurring radionuclides in some traditional medicinal plantsused in Nigeria. Journal of Radiation Research and Applied Sciences, $p$. 208-215, 2015.

[12]. SASONGKO. E.B., WIDYASTUTI. E., PRIYONO R.E., Kajian Kualitas Air dan penggunaan Sumur Gali Oleh Masyarakat di Sekitar Sungai Kaliyasa Kabupaten Cilacap, Program Studi Ilmu Lingkungan Program Pascasarjana UNDIP. Jurnal Ilmu Lingkungan. Nomor 2 Volume Semarang, hal. 72-83, 2014

[13]. ALTIKULAC A., TURHANS., GUMS H., The natural and artificial radionuclides in drinking water samples and consequent population doses. Journal of Radiation Research and Applied Sciences, p. 578-582, 2015.

[14]. BAPETEN, 2017, Nilai Batas Radioaktivitas Lingkungan, Peraturan Kepala Badan Pengawas Tenaga Nuklir Nomor 7 Tahun 2017. Jakarta, 2017 